\title{
The transformative capacity of the commons and commoning
}

\section{Anne B Ryan}

This paper provided the source material underpinning a workshop on the commons and commoning, presented as part of the Alternatives for Transformation Conference, March 2013, NUIM

\begin{abstract}
This paper treats the commons and commoning as transformative practices, since they involve democratic self-organisation for the collective management of resources.

Commoning is also treated as an expression of social power and the paper considers the relationship of commoning to Wright's transformative logics of symbiotic and interstitial strategies. The role of the state is and its capacity to support and promote commoning in interstitial and symbiotic forms is also considered.
\end{abstract}

\section{Key words}

Commons, commoning, aspirational commons, common-pool resources, social power, symbiotic, interstitial, state and commons, transformation, resources, self-organisation, democracy, ecology.

\section{Introduction}

This paper gives an overview of the concept of the commons and the principles underpinning the commons movement and treats them as emancipatory transformative practices.

Transformation is understood here as a change in social and economic forms, towards forms that are ecologically sound and socially just, which care for people, the earth and its resources, help a transition to low- or zero-carbon economies and are part of an important turn towards localisation, accompanied by a parallel sense of global challenges. Commoning is also transformative because it promotes self-organisation, social inclusion, and egalitarian participation, where care is taken to balance power among participants and to broaden the areas of people's lives that are based on democratic self-management.

In its simplest form, commoning is the collective management and maintenance of some kind of resource (Pór 2012: 217). The earth provides many natural common-pool resources, such as air, land, seeds, fresh water, the atmosphere with its carbon-absorbing capacity, airwaves, mineral deposits and the high seas or oceans. Some of these resources require local management and others need management on regional, national or global scales. Either way, a commons exists when a community or network decides that a resource should be managed for the benefit of all and that no single decision-maker should determine how the resource be used.

A central premise of the paper is that commoning is an expression of social power, that is, 'power rooted in collective association in civil society' Wright (2010: 194). The paper also considers the relationship of commoning to Wright's (2010; 2012) transformative logics, especially symbiotic and interstitial transformations, in the struggle against capitalism. Commoning can occur as interstitial enterprises (Wright 2010: Ch 10), running in parallel with the state and the state can also choose to support such enterprises. The state also has the capacity to initiate symbiotic strategies (Wright 2010: Ch 11) that harness common-pool resources for the common good. While these symbiotic activities are not commoning per se 
they are worthwhile because they transfer value from the common pool to all residents, not just those who are actively participating in commons enterprises; and they are achievable within the present capitalist system. Both interstitial commoning and state-led capturing of common-pool resources can develop public awareness of the existence of common-pool resources and can promote literacy about the commons.

The rest of this paper draws on recent writing by commons activists (Bollier 2013; Bollier and Helfrich 2012; Davey 2012) to provide an overview of the commons movement and how it fits into a general movement for transformation to participative, just and ecologically sound social economies. It gives a brief description of some existing interstitial commons in local and international contexts and outlines and supports plans to manage the atmosphere as an aspirational commons (Jopling 2012; 2013). The paper then considers how the state can initiate symbiotic strategies to support existing commoning practices, advocating a public money supply (Mellor 2010; Robertson, 2012) and state management of the common-pool resource of land-values (Ó Siochrú 2012) in ways that are compatible with the principles of commoning. The paper concludes that commoning is a politically and personally significant element of any broad vision for positive futures.

\section{The commons movement}

Commoning is an ancient practice and while so-called developed societies have lost a lot of knowledge about it, commons thinking and practice are very advanced among some groups, mostly in the least 'developed' societies (Davey 2012; Kenrick 2012). The present-day commons movement is reasserting historical and contemporary knowledge bases concerning commoning and its recognition of human needs, its valuing of participation and the collective management of resources. The movement is refining this knowledge and taking it forward to use it in present conditions.

Commons activists see themselves as part of a general movement to create participative local and global social economies capable of sustaining us in the face of contemporary environmental, individual and social difficulties. The right to basic securities is one of the key arguments for treating common-pool resources as commons (cf Bollier 2013: 14). People need basic securities if they are to be able to ride out various shocks and difficulties in life and participate in politics, society and democracy. In general, the commons movement is part of attempts to create economies based on principles of sufficiency and equality in the meeting of people's needs: provisioning economies (Mellor 2010) which are also socially just. Such social economies create basic securities at the broad parameters of society and economy and facilitate maximum creativity and diversity for individuals, communities and networks, within those parameters.

The commons movement acknowledges environmental limits and the dependence of human societies, economies and well being on natural systems and ecosystems. Many commons activists assert that this view must be at the centre of all human practices and systems of government (Bollier and Helfrich 2012). They view the maintenance of ecological stability as crucial. Central to achieving such stability is the setting of limits in the use of natural resources. This includes the common-pool resource of the atmosphere where we dump gas emissions and it means aiming for zero-carbon societies. It may also mean deciding to leave natural mineral resources such as oil or gas untouched, if it was concluded that the disadvantages of extracting them would outweigh the advantages to the community. 
For example, using commons principles, a community might decide to leave shale gas in the ground rather than extract it through hydraulic fracturing (fracking).

The commons movement is founded on a belief that humans have the inherent capacity to be cooperative, participative and to share resources (Davey 2012) and to devise a social system that fosters these capacities (cf Bollier 2013: 4). Commons-construction draws on human capacities for cooperation and sharing and at the same time develops them. Commoning recognises that individuals are partly formed through their contribution to and participation in the whole, and through the recognition that they receive from the communities and networks in which they participate. The human person at the heart of commoning is relational and lives with a sense of possibility for change and the practices of commoning implicitly critique the self-interest view of humans that dominates in capitalism. When people participate in a commons regime, they see that each person's contribution matters and that their efforts have immediate, tangible results (cf Wright 2012: 22).

No single commons, community or network can meet all of a person's needs. Therefore, people can belong to and participate in many different commons, which nest together in different ways (Bolier 2013: 19. While only a certain group of people may benefit from a particular commons, commons regimes can learn from each other and can add their experience to the overall commons movement.

\section{Forms of commoning}

Indigenous forms of commoning in Europe developed around the management of natural local resources such as woodland, grazing land, fishing areas, or a pond surrounded by a group of landowners. In some of these cases, a resource could be in private ownership but its usage was as a commons, with, for example, non-owners entitled to various rights such as grazing or cutting firewood (Linebaugh 2012: 119). In Ireland, commoning has long been practiced on land known as commonage, where farmers have agreed in advance how grazing land should be used, how many animals should be grazed and at what times of the year, in order to avoid overexploitation of the land. The best-known example is probably the Burren in Co Clare but there have been many others. Some of these commonages were neglected in recent years and there are current attempts to revive them (Joint Committee on Agriculture, Food and the Marine 2013).

The contemporary commons movement has supported the emergence of many newer forms of commons in civil society, including seed-saving, community gardens, membership farms, credit commons, small digital commons such as wikis and huge global digital commons such as Wikipedia.

Seeds are essential to human survival because everybody eats and needs access to healthy food, and seeds are the source of vegetable-based food. With open pollination, millions of farmers and gardeners around the world are able to save their own seeds or exchange seeds with each other. When seeds are genetically modified, they cannot reproduce through open pollination. This is a privatisation, which, quite apart from its biological hazards, carries huge social and ethical problems. It means that the only way farmers and growers can get seeds is by buying them from large corporations. A seed commons occurs when a community or network manages its seed stores and shares its stocks and knowledge with other communities. By practising commoning, members can be independent of commercial interests, feed themselves and earn a living without having to buy seeds, and this increases the self-reliance and resilience of a community. 
Communities can create different kinds of credit commons and can manage them as means of exchange. Local exchange and trading systems (LETS) are a small-scale example. Credit commons also exist on a regional scale and use digital resources. Larger-scale regional credit-clearing exchanges also exist, such as the Wirtschaftsring-Genossenschaft (WIR) in Switzerland. WIR has its own accounting units, trade credits and internal currency (Greco, 2012: 233). In a system like this, money functions as a social agreement or a store of value on which a community agrees (Eisenstein 2012: xviii).

In both membership farms and community gardens, members self-organise to manage local pieces of land and they also learn kitchen skills, an appreciation of the earth, connection with other members, food empathy, and skills of cooperation and participation. These enterprises are not owned by anybody, but managed cooperatively. In community gardens, members work the land themselves. Membership farms (usually referred to as CommunitySupported Agriculture or CSA) function as not-for-profit businesses where members pay a fee and farmer/s receive a wage to produce food for them. By paying in advance, the members share the financial risk with the farmers and with each other.

Many of these newer commons are part of a serious attempt that communities are making to re-localise. Small-scale commons, whether new or long-established, usually have tight boundaries and a limited membership. They meet material needs for their members, but they also provide experience in the principles and practice of commoning. 'The local commons is managed as a place where one can raise awareness about a new concept of publicness, while simultaneously demonstrating that there are indeed alternatives -- common usage in place of private property; local quality of life instead of remote-controlled consumption, as it were; and cooperation rather than individual isolation' (Mueller 2012: 221). These commons regimes show people that another world is possible and that if they work together, they acnbuild it in the spaces available.

As they self-organise, commons-members often come up against the forces that appropriated the common-pool resources in the first place (Kenrick 2012: 31). For example, it is very difficult for CSAs to get land to rent because landowners pay no fee on idle land and have no incentive to use it productively. Or a CSA may be permitted to farm land until someone wants to 'develop' it. Credit commons run into problems of taxation, because they are seen as unfair competition with the dominant money system, which is largely privatised. So commons activists have to push against the state and public policy to protect and expand the spaces where they are creating commons regimes, (cf Wright 2012: 22), often using legal and political means.

Digital commons exist at all scales, especially in the form of wikis. In a wiki, people cooperate online to generate ideas, without (but not excluding) face-to-face communication. Small wikis provide commons experience for members of learning or working groups. Huge digital commons with a global reach also exist, Wikipedia being one of the best-known examples. In addition, free software projects have agreed on programming priorities (Meretz 2012: 33) and open-source drugs for tropical diseases have been developed in this way.

Not all commons operate as perfectly democratic spaces. Wikipedia, for example, has been identified as having an editing atmosphere that can be confrontational and far from democratic. This deters many would-be participants. It also has huge gaps in the coverage of women and only ten per cent of its editors are women. Women have less free time than men 
to participate (Knibbs, 2013). Wikipedia's status as a commons is therefore under some question, since it lacks elements of democracy, equality and cooperation, which most commons activists consider essential to commoning (cf Bollier 2013: 9; McDermott 2014 forthcoming).

Commoning practices - or practices understood by their participants as commoning therefore take many forms and different groups of people have different ambitions for commoning. 'Some people may wish to use the commons to improve production or efficiencies' (Bolier 2013: 8). Nor do all commons share the ultimate goals of establishing ecological limits. The online global commons, for instance, requires communications technologies that consume vast amounts of energy and thus have a very big carbon footprint.

\section{The aspirational commons: Cap and Share}

The commons movement also aspires to create functional commons regimes for many global open-access common-pool resources, such as fresh water, the atmosphere and the high seas (Bolier 2013: 4). The movement asserts that every citizen of the globe should benefit from these resources but in many cases the resources have been privatised and overused, even destroyed (Davey 2012). Below is an outline of how the EU Emissions Trading Scheme (ETS) is such a privatizing vehicle. It is followed by a description of a commons framework for dealing with carbon emissions, called Cap and Share.

Under the ETS, it is accepted that we need to cap the amount of carbon-emisssions we generate, in order to mitigate global warming. The scheme issues permits to companies that need to burn a lot of fossil fuels - coal, oil and gas - in order to generate the energy that creates their products such as cement, electricity, glass, brick, paper and steel. These large energy users get most of their permits to emit free of charge, nevertheless they charge their customers for the permits. Their rationale for this practice is that the permits that they have received free of charge have a market value. Thus, when they surrender the permits they lose this market value and this is therefore one of their costs of production, for which their customers, the general public, should pay. Companies that pollute heavily are now making large profits (Daily Telegraph 2012).

The starting premise of commons-movement thinking concerning carbon emissions is that the carbon-absorption capacity of the atmosphere is a common-pool resource and that as citizens of the globe, we all have equal rights to 'dump' our waste gas emissions in the atmosphere within safe limits based on independent scientific assessment. Cap and Share, like the ETS, proposes a cap, which is enforced by requiring the large energy-users to have permits to bring fossil fuels into the economy. The major difference from the ETS is that each year, each adult in a particular country would receive a certificate for their share of the country's allowance of carbon emissions. The fossil fuel suppliers would have to buy these certificates via banks or post offices, and, taken together, the certificates become the permits. The more certificates they bought, the more fossil fuels the large companies could bring into the economy. Certificates would be in demand, and would fetch high prices in a legitimate market. ${ }^{1}$ As the Cap and Share website puts it: 'who's in charge of the permit system? WE are! So WE get the benefit from the sale of the permits' (Cap and Share n.d.).

\footnotetext{
${ }^{1}$ Under a version called Cap and Dividend, proposed in the USA, the permits are auctioned to the fossil fuel companies and the money is shared out equally among residents of a country.
} 
In order to pay for the certificates, the fossil fuel suppliers would put up the price they charge for petrol, heating oil, coal and gas. All fossil fuels and the carbon-intensive goods made from their energy would cost more, since the cost of capping carbon would be built into them automatically. But everyone would have more money from selling their share, to help them meet higher prices. The high cost of carbon-intensive goods would also encourage the use of low-carbon technologies and goods. The lower a person's carbon footprint, the more surplus money they would have. Carbon shares would be a form of currency for such time as people had surpluses to trade (Cap and Share n.d.; Matthews 2010, 2012). In addition, if an individual wanted to keep emissions down, they could withhold their surplus quotas from sale.

Under Cap and Share, countries that emit very little carbon compared with OECD and economically similar countries would now have a massive surplus of shares. Their citizens could turn these shares into financial wealth by trading. Provided the essential element of shares going directly to individuals was in place, everyone would be able to trade, creating income for all. This would alleviate poverty and help to give people genuine choices about migration. National economies could develop and prosper in ways uniquely suited to local conditions, without the 'structural adjustments' currently forced on them as conditions of aid packages.

So far, no government or union such as the EU has promoted Cap and Share or participated in efforts to create a worldwide structure to implement it. This is probably because the fossil-fuel and energy business sectors - the forces that have appropriated the global common-pool resources in the first place -- are closely intertwined with the state. For decades, powerful energy corporations have had a major influence on state and EU energy policies.

If states or super-states such as the EU do not drive such a measure, how can a global commons for the atmosphere be achieved? This serious challenge has resulted in proposals for a Global Climate Commons Trust, an initiative of global citizens. The Trust would introduce and administer a global Cap and Share scheme, and invite states to endorse and legitimise its operations on their territories. Its constitution could allow for other global commons functions to be added later. 'The Trust would be a recognised legal entity able to establish relationships with other entities including states; and obligations written into the constitution of the Trust to ensure transparency and accountability would be enforceable in courts of law' (Jopling 2012: 108). Individuals, communities and networks would pressurise their governments to sign up to this global trust. Activist members of the Feasta Global Climate Commons Group are currently working on this initiative and sometimes cite as inspiration The International Red Cross, which was a people's initiative eventually ratified by governments in the Geneva Convention (Jopling 2013).

\section{The state and the commons}

The examples of commons and aspirational commons given above are beyond the state, being interstitial activities of civil society (cf Wright 2010: 304-5). The Global Climate Commons Trust would of course interact with states and super-states, inviting them to endorse Cap and Share at such time as the Trust comes on stream, but it would remain beyond the state in its organisational structures. The state can also ensure that where small local commons exist, state policies do not work against them. This requires an adjustment of aspects of the 
prevailing system, in other words, symbiotic strategies (Wright 2010: 306) that can enable commons where they already exist or are starting up and which can also show the potential of commoning and make more commoning practices possible in the future. For example, the state can ensure security of tenure for community gardens and community-supported agriculture. Obstacles such as taxation should not be placed in the way of credit commons. It can also support efforts to revive traditional commonage, as in Ireland at this time.

\section{Symbiotic state mechanisms supportive of commons principles}

Commons-movement activists can also push for more proactive political decisions about how the state representing the community at large, can initiate symbiotic strategies to manage common-pool resources that cannot be managed on a local level. Two symbiotic strategies outlined below, which states can use, are the management of a democratic public money supply and the collection of economic rents in the form of land- or site-value taxes (LVTs and SVTs). These strategies contain elements of commons thinking; they have transformative capacity insofar as they support greater resilience and sustainability. They are also do-able within the present capitalist system though in the long run they are not optimal for those who benefit most from the system at present (cf Wright 2012: 22). While these moves are not commoning per se, they share commoning principles and take us further along a trajectory towards a more comprehensive transformation in the future (cf Wright 2010: 307).

\section{Public money supply}

States and currency unions could bring money under democratic management, so that it is not owned by any individual or group. Democratic monetary reform, in order to provide a public money supply, would require the state, local authority or currency union to issue debt-free money, control the interest-bearing issue of money by banks and end fractional-reserve banking (Robertson 2012).

The privatised issue of money, where banks issue money as debt and demand interest on it, has become the norm over the last forty years or so. This system drives indeterminate and exponential economic growth. It forces people to generate money through growth, to pay the interest on the loans they have assumed, and, in the case of businesses, to turn a profit (Kennedy 2012: 15). This system is undemocratic and has fuelled vast social and environmental damage.

A public money supply is not the same as a credit commons, but it shares an important foundational principle with commoning: money is a social resource, which should exist to benefit everybody. A public money supply can exist smoothly alongside credit commons and local currencies and it is important to have a mixture of money systems (Douthwaite 2010).

Where there is a public money supply, money functions as a common wealth, benefiting all (Mellor 2010: 159). It is also the money system in which so many other initiatives like public banks, interest-free banking (such as the Swedish JAK bank) or state investment banks are embedded (Kennedy 2012). Monetary reform in this mode could also be the way to finance a universal basic income, providing a floor of financial security for all (Robertson 2012). In turn, a basic income would support the individual members of the many pioneering groups already engaged in commoning practices (and other forms of transformation) in the interstices of society.

\section{Land- and site-value taxes}


Even though most land in Ireland is in private ownership, the nature of the ownership can be adjusted to capture the value that accrues to the land through the efforts of local communities and investment from the public purse. The value of land is a common-pool resource and landand site-value taxes (LVTs or SVTs, sometimes known as land rent), establish the principle that anyone who profits from the value added through the public purse or through the community should pay a fee (Ó Siochrú 2011; Robertson 2012:129). LVT is therefore a type of property tax, but it does not apply to buildings or to improvements to buildings.

Most of what causes the increase in sale-price of land over time arises from the activities of other people and of the state in the area where the land is located. As a simple example, prices of land and sites around the LUAS (rapid-transit) line in Dublin increased greatly. This was not due to the efforts of landowners but to public investment. Everybody in the state is entitled to a share in the benefits from the increased land values. Land values form a common-pool asset or resource, which smaller communities cannot manage. Therefore there is a role for the state to represent the community at large in this case.

Some people own land by chance, some own it because they buy it in a speculative bid to possess land whose value will increase in the future. Either way, when the value rises, it is not due to the efforts of the landowner. There is a case for state intervention to collect the rent. The state is not functioning as a commons per se, but it is ensuring that value from the common-pool resource is returned to the public purse. The state may choose to invest the money in public goods or it may pay dividends to individuals. A strong argument is made that it is the state's duty to collect the revenue but not to use it and instead to distribute a dividend to each resident, who then has the right to decide how they use their individual dividend (Mellor 2011; Robertson 2012). Cap and Share is based on the same kind of principle.

Within a commoning paradigm the important thing is that no single decision-maker should determine how the resource be used. Dividends ensure that every individual can decide how to use their share of the resource. In the absence of a dividend to each individual resident, participatory budgeting would be a step in the right direction. If the state were to make the decision about how to use the resource, that would be a statist form of public ownership and would not increase social power as advocated by Wright (2010; 2012).

Canada, New Zealand, Denmark, Hong Kong, Australia and parts of the US and South Africa have LVTs (Ó Siochrú 2012); none of them issues the revenue as dividends but even without this element in place, the capture of land values through rents prevents property bubbles, keeps rents down and supports community economies. It can also play a part in reducing carbon emissions, because it prevents leap-frog development and sprawl. Without LVTs, sites are left empty because nobody is willing to pay the price asked for them, and instead developers move further into the countryside where land-prices are not so high. This results in urban sprawl and people have to travel long distances to work, which results in increased carbon emissions and a lot of time spent commuting, which is time not spent in civil society.

LVTs and SVTs make it less attractive for someone to buy and retain land in the hope that its sale-price will increase because they are paid on all land, even if it is not being used. A fee on land or a site, even if it is idle, provides an incentive to the owner to use the land or site, to rent it or to sell it on to someone who can develop it. In addition, because owners of land cannot make huge profits on it, they may use their capital for more economically healthy 
enterprises than land speculation (Ó Siochrú 2012) and these enterprises will most likely need employees.

Where LVTs are in place, huge profits cannot be made from land speculation and banks are no longer prepared to lend to the landowner using the future value of the land as security. This prevents bubbles and keeps stable the prices of homes, freeing people from slavery to exorbitant mortgage repayments. In turn, this eases stress and pressures on personal and family budgets. As with basic income, it allows people to work shorter hours for pay if they wish, thus having more time for caring work and for participation in civil society, including commons of various kinds.

LVTs also keep down rents and allow small local businesses, including not-for-profit enterprises, to thrive. Often, when small independent businesses develop in an urban or suburban area, the area becomes lively and desirable and then property owners increase the rents. But this increase makes the area unaffordable for the small local businesses, they leave and larger chains and multiples move in, which can afford the rent. With their advent, the area loses its unique local character, along with the commitment and local knowledge of the small business-owners. The transition to a transformed social economy requires stable house prices, along with support for care work and small local enterprises. LVTs are an example of how the state management of a common-pool resource can help all of these transformations.

\section{Conclusion}

The premise of this paper is that part of a transition to a transformed economy and society -low-carbon, equal, democratic, supportive of care for people and planet, where there is more social power and conditions for participation in public life -- requires interstitial commons, state support for interstitial commoning practices, and proactive symbiotic moves from the state to capture common-pool resources and manage them for the benefit of all residents. There is no unitary design for transcending capitalism; there is, rather, a need for pluralism in the practices of transformation (Wright 2012: 22), and commoning is one of those practices.

Interstitial commons regimes vary, depending on location, the resource involved and the historical, social, political, ecological and human realities in play. 'Each commons is oneof-a-kind, managed by a specific community as a social system’ (Bolier 2013: 5). Interstitial commoning is part of building different ways of being in the world, in whatever spaces are possible. As people collectively build new commons regimes and restore old ones, they get a sense of the possible and literacy about commoning and common-pool resources increases. Different kinds of commons have useful knowledge to share with each other and political awareness of the global scene can develop, as commons-members exchange knowledge with commons regimes in other parts of the world. Experience of local and small-scale commons can also be useful in the very challenging task of developing global commons for the management of open-access common-pool resources.

Symbiotic strategies through the state can help open up greater space and support for interstitial innovations (cf Wright 2012: 21). Commoning is a way of seeing the world and acting in it which is quite different from privatisation or statism. These days, privatisation dominates and our so-called 'developed' world is organised largely around enclosure and marketisation. The state has aligned itself with these practices and has become a vehicle by which common-pool resources have been privatised. However, even as one asserts that the state should support the commons, there is a need to recognise that the state is losing power 
and influence to various forms of supranational powers that promote privatisation, such as the World Trade Organisation and large corporations.

Supporting commoning would require the state to make policy shifts that recognise human needs and to support people's right to benefit from common-pool resources and to practice self-organisation. The state would need to treat these rights as fundamental, distinct from, though not incompatible with, the rights of individuals to own private property. In supporting commoning practices, the state is not required to eliminate capitalist markets, but to enable a re-balancing in power relations and to weaken the power of the market in relation to the state and to social power, that is, the power of the people or the commoners (cf Wright 2010: 121, 129).

There is a role for public ownership and management in the transformative agenda and they are the most commonly recognised alternatives to privatisation. But public ownership can result in a decrease in social power, since public bodies can become very big and distant from the people they are supposed to serve. In the absence of awareness of commoning, people become disillusioned and turn to the option of privatisation. However, when people learn about commoning, especially when they learn through participation, it can have a powerful appeal because of its elements of self-organisation, social inclusion, egalitarian participation and its capacity to broaden the areas of individuals' lives that are democratically self-managed. In the case of the global commons, there is also a recognition of the essential fairness of organising common-pool resources in such a way that every individual citizen of the globe benefits. The current resurgence in commoning ideas and practices presents an opportunity to go beyond dominant thinking about public vs private management of resources, and can contribute to increasing social power. Commoning is part of a broad vision for a positive future for society and economy. Its transformative capacity is significant for both politics and subjectivity; it continues to evolve in multiple forms, as new challenges emerge, especially regarding environmental limits and the dependence of human societies and personal well being on natural systems and ecosystems.

\section{Note}

The author wishes to thank two anonymous reviewers for their very helpful comments. Any shortcomings remain the responsibility of the author.

\section{References}

Bollier, David (2013) European Deep Dive Report. Pontoise: The Commons Strategies Group

Bollier, David and Helfrich, Silke (2012 eds.) The Wealth of the Commons: A World Beyond Market and State. Amherst, MA: Levellers Press.

Cap and Share (n.d.) http://www.capandshare.org/howworks_basicidea.html Accessed 21 January 2014.

Daily Telegraph (2012) 'EU Carbon Trading Windfalls Under Fire From Lord Turner', http://www.telegraph.co.uk/finance/newsbysector/energy/7354751/EU-carbon-tradingwindfalls-under-fire-from-Lord-Turner.html. April 16th. Accessed 16 April 2013

Davey, Brian (2012 ed.) Sharing for Survival: Restoring the Climate, the Commons and Society. Dublin: Feasta.

Brian Davey (2012) 'What Can be Done if Mainstream Politics Loses Interest in Climate Change?', pp 1-22 in Brian Davey (ed.) Sharing For Survival: Restoring the Climate, the Commons and Society. Dublin: Feasta 
Douthwaite, Richard (2010) 'The Supply of Money in an Energy-Scarce World', pp 58-83 in Richard Douthwaite and Gillian Fallon (eds.) Fleeing Vesuvius: Overcoming the Risks of Economic and Environmental Collapse. Dublin: Feasta

Eisenstein, Charles (2012) Foreword, xiii-xviii in Margrit Kennedy Occupy Money. Gabriola Island: New Society Publishers.

Greco, Thomas H (2012) 'Reclaiming the Credit Commons: Towards a Butterfly Society', pp230-235 in David Bollier and Silke Helfrich (eds.) The Wealth of the Commons: A World Beyond Market and State. Amherst, MA: Levellers Press.

Joint Committee on Agriculture, Food and the Marine (2013) Report on Review of Commonage Lands and Framework Management Plans. Dublin: Houses of the Oireachtas Jopling, John (2012) 'Operating Effectively at the World Level', pp 95-119 in Brian Davey (ed.) Sharing for Survival: Restoring the Climate, the Commons and Society. Dublin: Feasta. Jopling, John (2012) 'Co-creating a Global Climate Commons Regime’. Alternatives for Transformation Conference. Maynooth: March 2013.

Kennedy, Margrit (2012) Occupy Money. Gabriola Island: New Society Publishers.

Kenrick, Justin (2012) 'The Climate and The Commons', pp22-47 in Brian Davey (ed.) Sharing for Survival: Restoring the Climate, the Commons and Society. Dublin: Feasta. Knibbs, Kate (2013) 'Wikipedia has a gender problem. Can it be fixed?' meta.wikimedia.org/wiki/WikiWomen's_Collaborative. Accessed 11 Nov 2013 Linebaugh, Peter (2012) 'Enclosures from the Bottom Up', pp 114-124 in David Bollier and Silke Helfrich (eds.) The Wealth of the Commons: A World Beyond Market and State. Amherst, MA: Levellers Press.

McDermott, Mary (forthcoming 2014) Editorial, 'Special Supplement on The Commons', Community Development Journal. http://cdj.oxfordjournals.org/

Matthews, Laurence (2010) 'Cap and Share - Simple is Beautiful', pp 244-256, in Richard Douthwaite and Gillian Fallon (eds.) Fleeing Vesuvius: Overcoming the Risks of Economic and Environmental Collapse. Dublin: Feasta

Matthews, Laurence (2012) 'Cap and Share in Pictures', pp 48-60 in Davey, Brian (ed.) Sharing for Survival: Restoring the Climate, the Commons and Society. Dublin: Feasta. Mellor, Mary (2010) The Future of Money: From Financial Crisis to Public Resource. London: Pluto Press.

Meretz, Stefan (2012) 'The Structural Communality of the Commons', pp 28-34 in David Bollier and Silke Helfrich (eds.) The Wealth of the Commons: A World Beyond Market and State. Amherst, MA: Levellers Press.

Mueller, Christa (2012) 'Practicing Commons in Community Gardens: Urban Gardening as a Corrective for Homo Economicus', pp 219-224 in David Bollier and Silke Helfrich (eds.) The Wealth of the Commons: A World Beyond Market and State. Amherst, MA: Levellers Press. Wright, Erik Olin (2010) Envisioning Real Utopias. London and Brooklyn: Verso. Wright, Erik Olin (2012) 'Transforming Capitalism through Real Utopias', American Sociological Review published online 26 December 2012.

Ó Siochrú, Emer (2012 ed.) The Fair Tax: Supported by History, Agreed by Economists, Feared by the 1\%. London: Shepheard Walwyn.

Pór, George (2012) 'School of Commoning', pp 217-218 in David Bollier and Silke Helfrich (eds) The Wealth of the Commons: A World Beyond Market and State. Amherst, MA: Levellers Press.

Robertson, James (2012) Future Money: Breakdown or Breakthrough? Totnes: Green Books. 